\title{
Climate change and urban development in southern Africa: The case of Ekurhuleni Municipality (EMM) in South Africa
}

\author{
SJ Piketh ${ }^{1 *}$, C Vogel $^{2}$, S Dunsmore ${ }^{3}$, C Culwick ${ }^{4}$, F Engelbrecht ${ }^{5,6}$ and I Akoon ${ }^{7}$ \\ ${ }^{1}$ Climatology Research Group, Unit for Environmental Science and Management, North-West University, Private Bag X6001, \\ Potchefstroom, 2520, South Africa \\ ${ }^{2}$ Department of Geography, Geoinformatics and Meteorology, University of Pretoria, Private Bag X20, Hatfield, 0028, South Africa \\ ${ }^{3}$ Fourth Element Consulting, 18 Clamart Rd, Richmond, 2092, South Africa \\ ${ }^{4}$ Gauteng City-Region Observatory a partnership between the University of Johannesburg, the University of the Witwatersrand, \\ Gauteng Provincial Government and organised local government; Private Bag 3, WITS, 2050, South Africa \\ ${ }^{5} \mathrm{CSIR}$ Natural Resources and the Environment - Climate Studies, Modelling \& Environmental Health

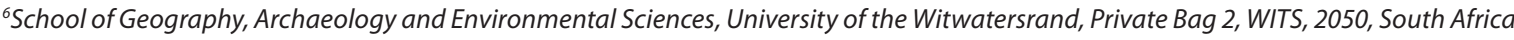
${ }^{7}$ Ekurhuleni Metropolitan Municipality, PO Box 25, Edenvale, 1610, South Africa

\begin{abstract}
In this paper, outcomes from an investigation of plausible climate futures over the next century, and the potential impacts on water services including water resource management and disaster risk reduction, such as flash flooding in Ekurhuleni (EMM), are presented. Four key aspects are examined: (i) the extent to which the frequency of extreme rainfall events may change in South Africa as a result of climate change; (ii) the identification of some of the implications of extreme rainfall events for local government (iii) the identification of some of the challenges communities most at risk of flooding as a result of extreme rainfall events face, finally, (iv) the opportunities for future co-production of design methods and approaches to reduce current and future climate risks in EMM and elsewhere. Climate modelling conducted for this research indicates that it is plausible for an increase in the number of extreme rainfall events to occur over central and eastern South Africa over the next century. Over EMM, for example, an increase in extreme rainfall events is likely to be accompanied by flash flooding and a range of deleterious impacts, if planning and maintenance of the water services infrastructure is not improved - a result that is likely to be valid for all large metropolitan municipalities in the country. The paper provides some lessons learnt when trying to include a climate risk reduction approach into the planning of urban development.
\end{abstract}

Keywords: Flash flooding, urban risk environments, climate change and climate variability

\section{INTRODUCTION}

Water services management is likely to be one of South Africa's most complex problems for municipalities in the future. Trends towards greater urbanisation and densification, coupled with environmental changes such as climate change and variability, are likely to exert additional pressure on water resources at the local level (Wilbanks et al., 2007; Bartlett et al., 2009; Carmin et al., 2009; Yohe and Leichenko, 2010). Careful management of water supply challenges and associated potential disaster risks that may arise with climate change will be essential (Wilbanks et al., 2007; Shama and Tomar, 2010; Yohe and Leichenko, 2010; Government Office for Science, 2012). Projections for South Africa include the possibility of more intense and heavy rainfall in some areas that may then trigger flash flooding events (LTAS, 2014). The South African Weather Service is, for example, developing timely flash-flooding guidance systems that can be used by practitioners to reduce the risks of floods (Poolman, 2014).

As illustrated in this paper, climate change projections are decision-making tools that can be used in planning horizons, particularly those that aim to address climate and development issues in both the short and longer term. Climate-related risks

\footnotetext{
To whom all correspondence should be addressed.

+27 18299 1582; e-mail: stuart.piketh@nwu.ac.za Received 24 July 2013; accepted in revised form 2 October 2014.
}

are outlined for a large municipality in Gauteng, Ekurhuleni Metropolitan Municipality (EMM). Local comparable work on climate risk reduction, similar to that undertaken in Cape Town (e.g., Cartwright, 2008; Cartwright et al., 2012), the Northern Cape (e.g. Mukheiber and Sparks 2006; Mukheiber, 2007) and Durban (e.g. Roberts, 2008, 2010a and 2010b), is largely absent in Gauteng. Widespread flooding or intense localised rainfall (flash floods), for example, can unleash a range of impacts that often exacerbate existing vulnerabilities. Water resources management implications for the EMM are explored in this paper by considering the current management of flash-flooding episodes, perceptions of flood risk management and some adaptation options.

\section{Climate modelling and possible planning implications}

Several studies of observed trends in climate, climate models, and model projections are available for long-term urban planning. In an analysis of observed trends in annual rainfall over South Africa, Kruger (2006), on the one hand, found no statistically significant trends in local observation data at the majority of stations. There is, however, spatial coherence between the trends recorded independently at different weather stations, which suggests a tendency for rainfall to be decreasing over parts of north-eastern South Africa, including Limpopo and the north-eastern Free State. On the other hand, a consistent pattern of rainfall increases has simultaneously been observed over central South Africa, including the North-West Province, 
the western Free State and northern interior of the Eastern Cape. Consistent with these results, increases in the length of wet spells and heavy rainfall events have been recorded over central South Africa (Kruger, 2006).

Regional climate modelling continues to be used to provide updated, multi-decadal projections for rainfall and temperature over southern Africa (e.g. Mason and Joubert, 1997; Tadross and Hewitson, 2005; Hewitson and Crane, 2006; Engelbrecht et al., 2009; Engelbrecht et al.,2011; Engelbrecht et al., 2012; Malherbe et al., 2012). In general, these studies project that it is plausible for the central to eastern parts of South Africa to become wetter, whilst the western parts and in particular the winter rainfall region of the south-western Cape are projected to become drier.

Importantly, the projections also provide evidence that the increase in annual rainfall may be associated with an increase in the frequency of possible extreme rainfall events (Engelbrecht et al., 2012), which is consistent with findings from Kruger (2006). In the wider field of study indications of projected changes with varying degrees of certainty include:

- 'It is likely that the frequency of heavy precipitation or the proportion of total rainfall from heavy falls will increase in the $21^{\text {st }}$ century over many areas of the globe' (IPCC, 2012, p. 11).

- 'There is medium confidence that droughts will intensify in the $21^{\text {st }}$ century in some seasons and areas, due to reduced precipitation and/or increased evapo-transpiration'. This applies to various regions including southern Africa (IPCC, 2012 p. 11).

Effective adaptation to climate events (including storm risks and flooding) combines measures to reduce the impacts of current climate hazards and future risks identified in climate change projections. Improving the understanding of current and future storm risks and associated impacts, e.g., flash flooding, is not only of scientific value, but is also extremely valuable for a range of communities, not least those that may be vulnerable (Carmin et al., 2009; Roberts, 2008 2010a, 2010b). Efforts therefore also need to be made to understand how climate risks, including flood risk, are framed and perceived by those most affected.

Early identification and understanding of potential risks and vulnerabilities can enable the implementation of measures that can enhance resilience to change (e.g., The Government Office for Science, 2012). Effective adaptation to climate events combines measures to reduce the impacts of current climate hazards and future risks identified in climate projections to prevent hazards becoming disasters. As we show in this case study, perceptions can add a wealth of important information when planning for change (Granberg and Elander, 2007; Moser and Satterthwaite, 2009; Bartlett et al., 2009; Lang et al., 2012).

\section{METHODOLOGY}

An integrated approach to managing climate change risk is necessary when examining local-scale adaptation to climate risks. In this paper a range of probing approaches was used to try to understand the local risk environment in which various communities and stakeholders operate. The perceptions and experience of relevant communities; the status quo of vulnerability and management in the municipality; climate change projections (downscaled to a relevant scale) and interpretation of climate change projections (in this case using hydrological modelling) were all used.
An interdisciplinary team was used for the research undertaken, including engineers, hydrologists (including someone linked to Rand Water), a climate modeller, and geographers, including those working in the social dimensions of environmental change. At the outset of the project, and in keeping with a transdisciplinary focus, meetings on design and methods occurred with key city officials and their spatial planning team. From these interactions the team divided the work into work packages that then focussed on downscaling of climate models, 'upscaling' and better understanding of the hydrological system in the area where this was possible, and detailed interviews of the community and city officials on risk reduction and perceptions of flooding risks.

The methodology was also determined in conjunction with planners in the EMM through attendance at their strategic planning meetings. While it was not a fully applicable type of co-production and transdisciplinary approach, whereby a researcher works with a community of practice at the very outset of the research project including the design of the research process (in this case with local residents and with the municipality planners and other managers, see, e.g., Thompson Klein, 2004 and Lang et al., 2012), engagement with city officials enabled the 'team' (e.g. of planners, local managers and scientists) to have a meaningful dialogue on urban climate risk management.

\section{RESULTS AND DISCUSSION}

\section{Water resources management implications under changing climates}

Water resource management is a crucial activity for all spheres of government in South Africa and is highly vulnerable to climate change (Bates et al., 2008; DWA, 2013). On a regular basis, water resource managers have to consider factors that influence both the water quality and quantity within their particular sphere of government, including the source strength of the water, rainfall and river or stream flow, human activities such as agriculture and land-use change, construction and pollutants. These aspects need to be managed holistically (Miller and Yates, 2006; Bates et al., 2008).

A number of existing key challenges were identified by various EMM actors, several linked closely to a range of capacities, including human, financial and political, both in the country and, specifically, the EMM (Table 1). These challenges, are, however, not unique to EMM and similar issues have been raised in other studies in South Africa as well as in other parts of Africa (Mukheibir and Sparks, 2006; Mukheibir, 2007; Douglas, et al., 2008).

Potential changes in weather patterns under climate change may also introduce a number of new and additional challenges to water utilities in terms of their ability to provide safe, reliable potable water at the lowest possible cost. Although the technology to deal with most of these challenges is available, the cost of implementation may seriously hamper the cost-efficiency of water delivery into the future.

\section{Climate change and water resources - challenges for city managers}

Scientific evidence to date overwhelmingly indicates that anthropogenic-induced climate change is a real phenomenon that is currently occurring, and is likely to gather momentum towards the middle of this century. Climate factors that are 
TABLE 1

\begin{tabular}{|l|l|}
\hline \multicolumn{2}{|c|}{ Non-climate change challenges identified in water resource management in local authorities in EMM } \\
\hline Challenges & Description \\
\hline Human capacity & $\begin{array}{l}\text { A shortage of staff as well as the availability of skilled personnel adversely affects the effective manage- } \\
\text { ment of water resources. }\end{array}$ \\
\hline Infrastructure capacity & $\begin{array}{l}\text { Infrastructure maintenance and development is a cornerstone of providing services associated with } \\
\text { water. }\end{array}$ \\
\hline Financial constraints & $\begin{array}{l}\text { Budgets to develop, maintain and monitor infrastructure are constantly under pressure from other } \\
\text { activities within the municipalities and metropolitan authorities. }\end{array}$ \\
\hline $\begin{array}{l}\text { Institutional } \\
\text { communication }\end{array}$ & $\begin{array}{l}\text { Water resources management is not an activity that is undertaken by a single department. Inter- } \\
\text { departmental communication is required for better water management. }\end{array}$ \\
\hline $\begin{array}{l}\text { Political misalignment to } \\
\text { local needs. }\end{array}$ & The priorities of politicians can detract from effective water resource management. \\
\hline
\end{tabular}

significant for water resources are not homogenous across the globe or even in South Africa. Given some of the uncertainty in climate projections, it is crucial that potential climate change impacts on rainfall, and therefore the consequences for water as a resource, be modelled for different emission and economic scenarios, at the appropriate spatial scales (e.g. regional or municipal) to inform decision-making processes (Bates et al., 2008).

The research reported here utilises a set of high-resolution projections of future climate change over southern Africa, obtained using a variable-resolution global atmospheric model and implemented on the computer clusters of the Centre for High Performance Computing in South Africa. Typically, regional climate models can be integrated at the continental scale at resolutions of about $50 \mathrm{~km}$ and at various climate-change time scales (e.g. simulations for the period 1961-2100), whilst simulations at even higher resolutions can be performed over smaller areas (e.g. country, provincial or river-basin scales (Engelbrecht et al., 2011). A variable-resolution atmospheric global circulation model, the conformal-cubic atmospheric model (CCAM), was utilised to simulate future climates over southern Africa for the $21^{\text {st }}$ century. The projections of 6 different coupled global circulation models that contributed to Assessment Four (AR4) of the IPCC were downscaled to high resolution over southern Africa (Engelbrecht et al., 2011). The simulations spanned the period 1961-2100 and were obtained for the A2 emission scenario of the Special Report on Emission Scenarios (SRES). The model results yielded a few important findings that are crucial for consideration of future water resource management. The first is that it is plausible for maximum surface temperatures over southern Africa to increase significantly towards the end of this century (Fig. 1). This signal is robust across the ensemble of different downscalings. Daily maximum temperatures during the summer half-year are projected to increase by more than $4^{\circ} \mathrm{C}$ over the northern parts of South Africa including Gauteng, for the period 2071-2100 relative to the baseline period 1961-1990. These increases are higher than the projected global increases and highlight the need for careful planning.

Higher surface temperatures are likely to result in higher water evaporation and evapotranspiration. Although there is a complex set of mechanisms and regional feedback mechanisms that drive the aforementioned, some studies have indicated that a $2-4^{\circ} \mathrm{C}$ change in surface temperature could result in a reduction in runoff of between $4-12 \%$ and $9-21 \%$, respectively, if precipitation stayed constant (Nash and Gleick, 1993; Miller and Yates 2006).

In addition to the increases in temperature, specific attention was given in this research to the projected changes in

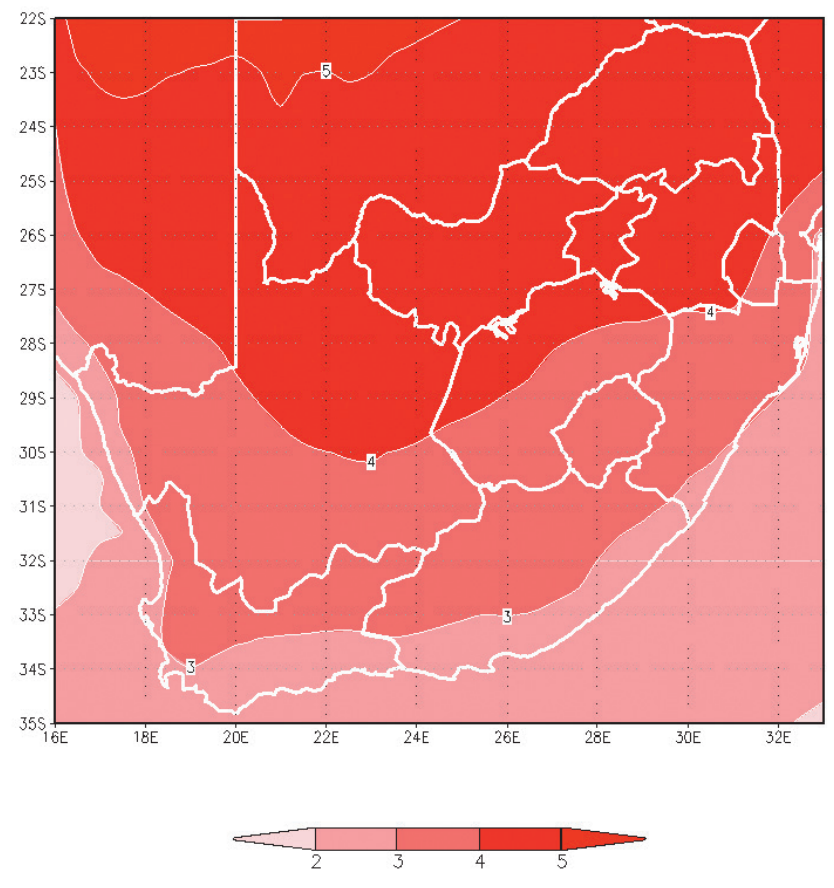

Figure 1

Projected change in maximum temperature $\left({ }^{\circ} \mathrm{C}\right)$ during the summer half-year over South Africa, for the period 2071-2100 vs. 1961-1990. The ensemble average is shown for an ensemble of downscalings of 6 different CGCM projections of AR4 of the IPCC, all for the A2 SRES scenario.

rainfall over the country for the same modelling period. Significant changes in rainfall totals over parts of the southern African region (e.g. Engelbrecht et al., 2012) and the occurrence of extreme precipitation events are projected under climate change (Fig. 2).

The ensemble-averaged projected change in the annual frequency of occurrence of extreme rainfall events over South Africa is shown in Fig. 2. An extreme rainfall event in the Gauteng region is defined as $20 \mathrm{~mm}$ of rain falling within $24 \mathrm{~h}$ over an area of $0.5^{\circ} \times 0.5^{\circ}$ (approx. $50 \times 50 \mathrm{~km}^{2}$ ). Rainfall events of this magnitude rarely occur over the South African Highveld (Dyson, 2009) and are likely to be associated with flooding over the region. A general increase in extreme rainfall events is projected for South Africa - another robust message from the ensemble of different projections obtained (not shown). Rainfall events are projected to increase over the mountainous regions 

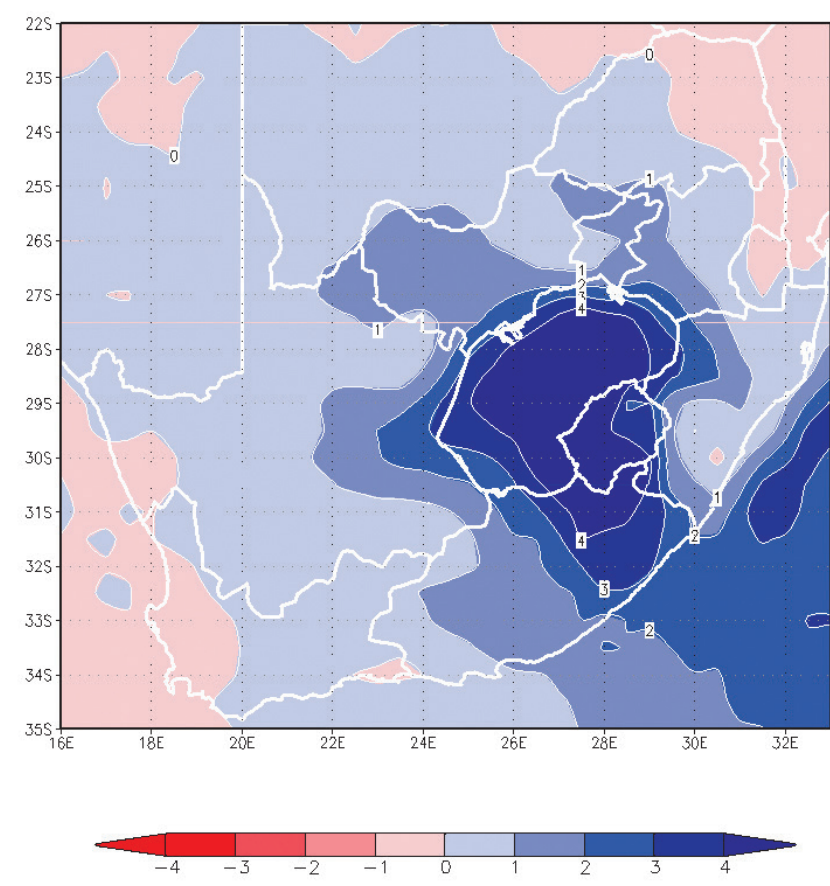

Figure 2

Projected change in the annual frequency of extreme rainfall events (defined as $20 \mathrm{~mm}$ of rain falling within $24 \mathrm{~h}$ over an area of $0.5^{\circ} \times 0.5^{\circ}$ ) over South Africa, for the period 2071-2100 vs. 1961-1990 (units are number of events per model grid box per day). The figure shows the ensemble average of the set of downscaled projections, obtained from 6 CGCM projections of AR4 of the IPCC, all for the A2 SRES scenario.

of eastern South Africa in particular - including Lesotho and the Highveld regions of Mpumalanga, Gauteng, and the Free State.

The projections of increased surface temperature and the likelihood of more intense rainfall episodes possibly leading to flooding and flash flooding has direct implications on the water resource management of local governments. Associated management issues include: disaster management, especially for floods but also droughts, and water storage and demand changes.

\section{Managing flooding and flash flooding}

Managing flash flooding in the South African context includes understanding impacts from both physical and societal factors, including governance and perception, that together contribute to change (Carmin et al., 2009; Bartlett et al., 2009; Roberts 2008, 2010a and 2010b; Fatti and Vogel, 2011; Fatti and Patel, 2013). A range of social factors, including allocation of budgets in the metropolitan municipality, political agendas and various other governance factors (e.g. Bulkeley et al., 2010), can either enhance or impede adaptive measures to environmental risks in cities.

Significant risk management of flash floods by local governments usually occurs directly after a flooding event as an immediate crisis response. The response can be slow, with typically no action occurring beyond the normal daily activities in cities (Colombo et al., 2002) unless a major disaster threatens. Calls are being made for a more mainstreamed adaptation approach and sufficient planning (including day-to-day planning activities) to minimise loss of life and property from

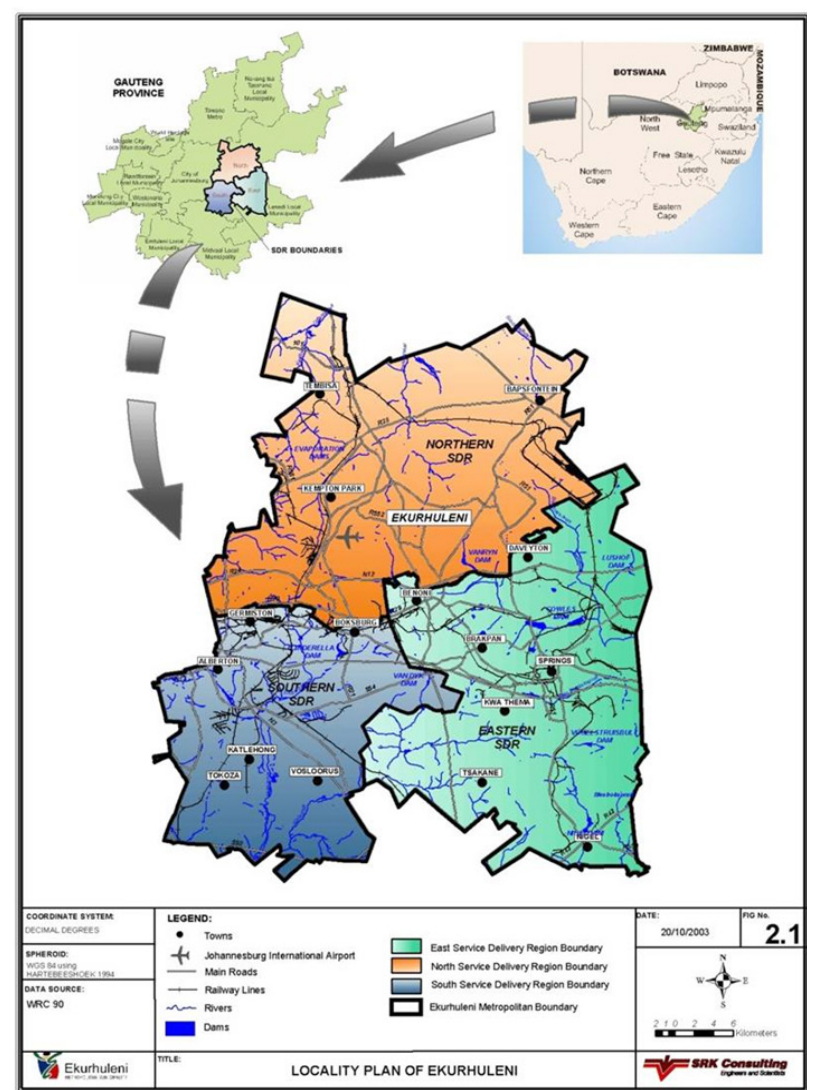

Figure 3

Locality of Ekurhuleni Metropolitan Municipality, including the three managerial districts

flash-flooding events, particularly before an event (Carmin et al., 2009; Roberts, 2010a and b; Yohe and Leichenko, 2010). In established urban areas, there are 3 primary components to managing extreme rainfall events at a local scale:

- Identifying the risk of a flash flood event

- Developing prevention and mitigation strategies (structural and non-structural) (Colombo et al., 2002)

- Developing a flood action plan in conjunction with the communities

In EMM, the actions outlined above are being undertaken with various degrees of success. What emerged from the research team's interaction with the practitioner, however, was not only a sense of the biophysical impacts and drivers of risk but also a deeper appreciation of the need for more careful interrogation and understanding of the human dimensions of risk generation and management. For the purposes of this paper, only some of the more salient points that show the need for more than a business-as-usual approach in municipalities are profiled.

\section{Climate change risk reduction: emerging lessons from the EMM case study}

EMM was formed in 2000 by joining several local municipalities of the former East Rand Region in Gauteng (Fig. 3). The population of EMM is approximately 3.1 million people (Stats SA, 2011). Population densities are high especially in former 'township' and informal residential areas. A larger percentage of Ekurhuleni's population is of working age; however, the rate 
of unemployment is high, at approximately 40\% (EMM SOER, 2004). Ekurhuleni's urban environment is similar to other South Africans cities with approximately $22 \%$ of the people living in settlements with inadequate housing and low or no access to basic services (Stats SA, 2011).

EMM falls within the summer rainfall region of South Africa and experiences hot, wet summers and cold, dry winters. The climate is generally mild, with a range of 17 to $28^{\circ} \mathrm{C}$ in the summer months (Dec, Jan, Feb) and 5 to $19^{\circ} \mathrm{C}$ in the midwinter months (Jul, Aug). Ekurhuleni experiences summer thunderstorms in the late afternoon. Average rainfall for the region is between 715 and $735 \mathrm{~mm} / \mathrm{a}$.

The topography of EMM is generally flat, ranging in elevation from $1460 \mathrm{~m}$ to $1760 \mathrm{~m}$. The topographical features that are prominent in EMM include: 'plains with pans; undulating plains with pans; undulating plains; superimposed river valley (i.e. Blesbokspruit) on plains with pans and ridges' (EMM EMF, 2007 p. 6). 'Pans directly linked to flat topography cover a total area of 3559 ha and are mostly seasonal' (EMM EMF, 2007 p. 10).

The natural hydrological systems in EMM (that comprise 6 rivers or 'spruits' (EMM EMF, 2007) have been significantly affected by pollution from sewage works, human settlements, mining and agricultural activities. The urban and infrastructure development has had a major impact on infiltration of water in EMM. It is estimated using EMM development data (EMM SOER, 2004) that urbanisation has resulted in an increase in surface water run-off by almost $300 \%$ above the natural catchment yield. There is an extremely high likelihood that more intense floods in the future pose a significant threat to informal settlements located on marginalised land which lies within the designated flood lines (EMM SOER, 2004).

\section{Susceptibility to flash flood hazards in EMM}

The topography of the area, paired with the impacts of urbanisation, has rendered EMM highly vulnerable to flooding, which will be exacerbated by the impacts of climate change. Development pressure on land within the EMM is directly related to urbanisation, growth in population, and the prioritisation of the industrial economy. With many areas in the region needing further land and infrastructure development to facilitate socio-economic development, increased potential for flash floods developing into high-level hazards is expected as natural areas are urbanised. Another key aspect, as highlighted by Douglas et al. (2008), is that poor communities usually live in the most hazardous and unhealthy environments in African cities (Akoon, 2010)

Despite the purpose and design of stormwater drains to reduce flood risk in urban and built-up areas, when these systems fail they can exacerbate flood risk. In many urban areas within EMM, streams are routed underground into stormwater drains, e.g., Nigel, Alberton and Springs. In other urban areas, the outlet of stormwater into natural streams considerably increases stream flow. This practise has the potential to compound damage caused during periods of heavy rainfall, as the storm drains become overwhelmed, and roads and buildings are flooded. The knock-on effect of the channelled water being released into streams downstream of the urban area adversely impacts on the natural systems by increasing the risk of more serious flooding (Akoon, 2010)

During the approval process for new developments in EMM, runoff mitigation measures are implemented; however, these are generally limited to provision of flood attenuation, which only manages peak flow, not runoff volume. When this

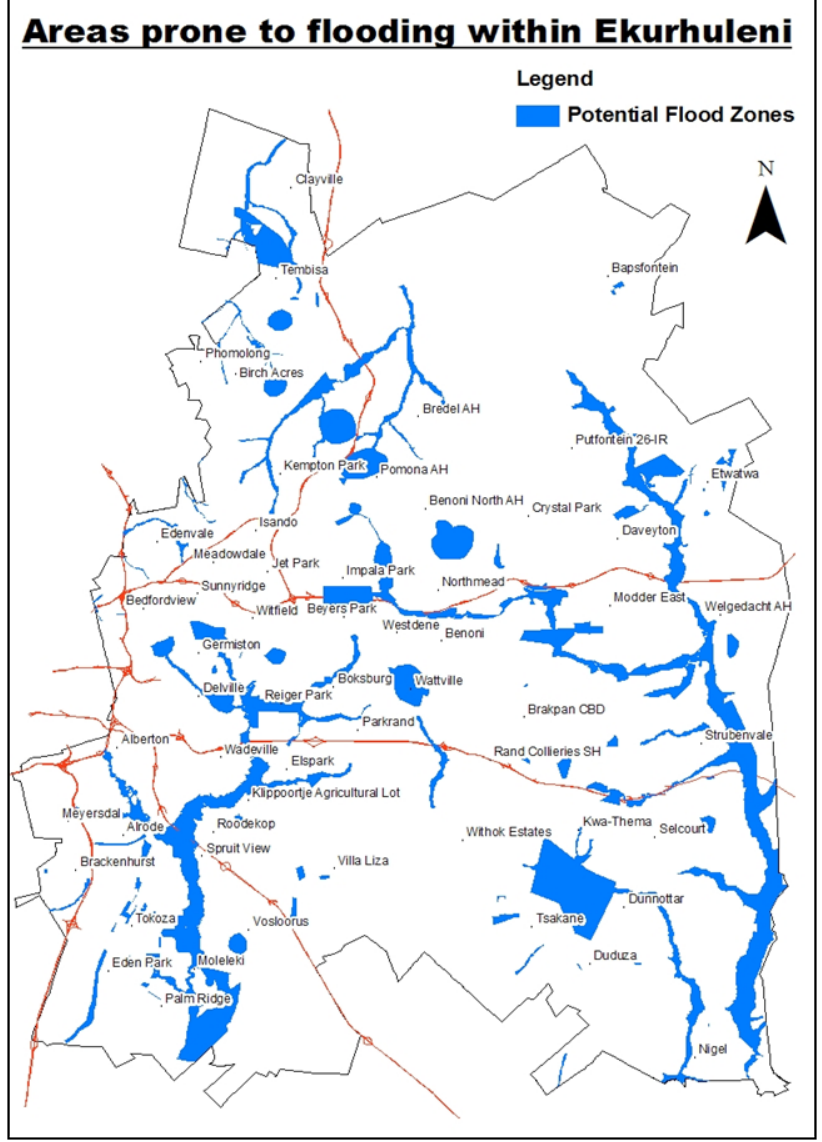

Figure 4

Areas prone to flooding in $E M M$

practice is applied in an ad hoc manner (i.e., without a stormwater master plan being implemented according to design), attenuation systems often have limited impact on overall urban catchment flood responses, and can even exacerbate flood impacts. Additionally, poor management and maintenance of existing stormwater networks can lead to sediment and debris build-up, and ingress of vegetation into drains, which in turn leads to blockages and increased damage to property and infrastructure (Akoon, 2010).

For this study, the risk of flash flooding within EMM was determined by mapping topography and flood lines together with reported cases of flooding (Fig. 4). In addition, vulnerability of the region to flooding was determined using a weighting scale to score a specific homogenous zone by social, economic, environmental and structural values. As may be expected, areas with informal housing and high population densities scored high on the scale, resulting in these areas being considered very high in terms of vulnerability (Fig. 5). The converse of this is evident for natural open spaces. The flash flood risk data were overlaid with the vulnerability assessment data to create a flash flood risk and vulnerability map for EMM. The results highlight that a significant portion of EMM is prone to flash floods ( $12.46 \%$ of the total area) (Fig. 6). The highest risk and vulnerability intersection points tended to be where inadequate infrastructure and poor planning of the urban environment coincided with close proximity to a watercourse, pan or low-lying topographic depressions (Akoon, 2010). 


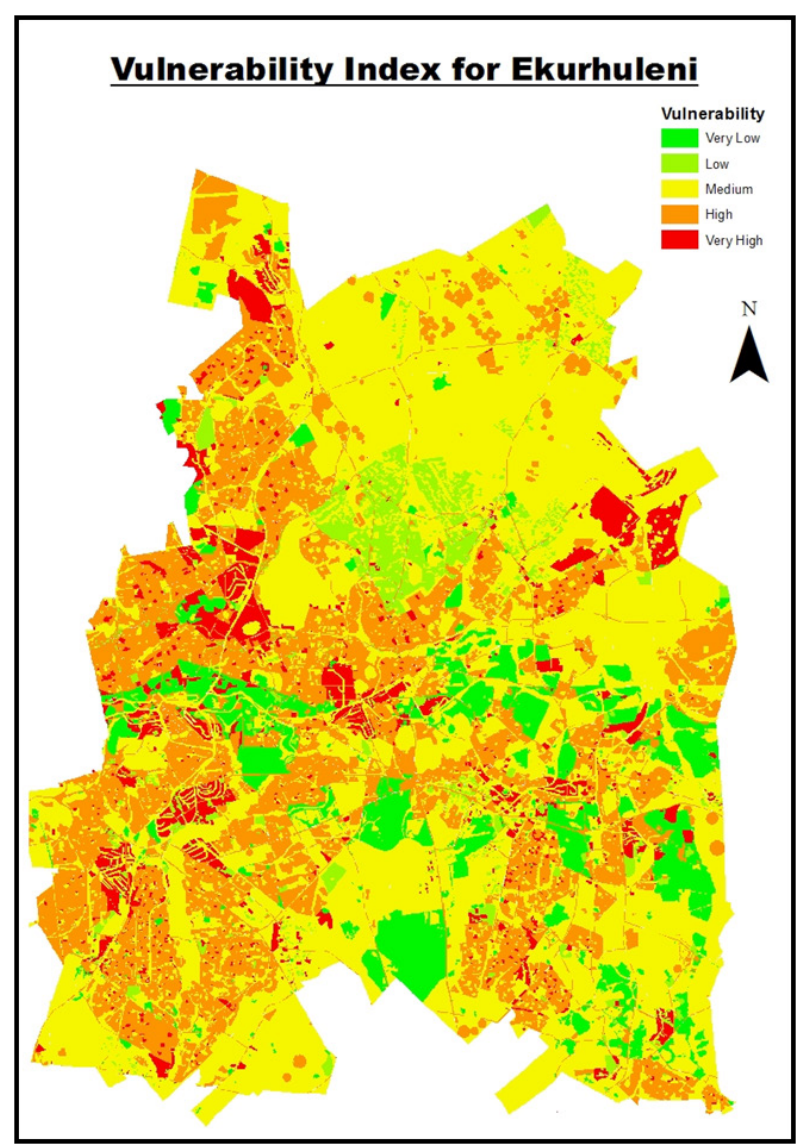

Figure 5

Vulnerability analysis for the EMM area. Red areas indicate the regions that are most vulnerable to flash flooding in Ekurhuleni.

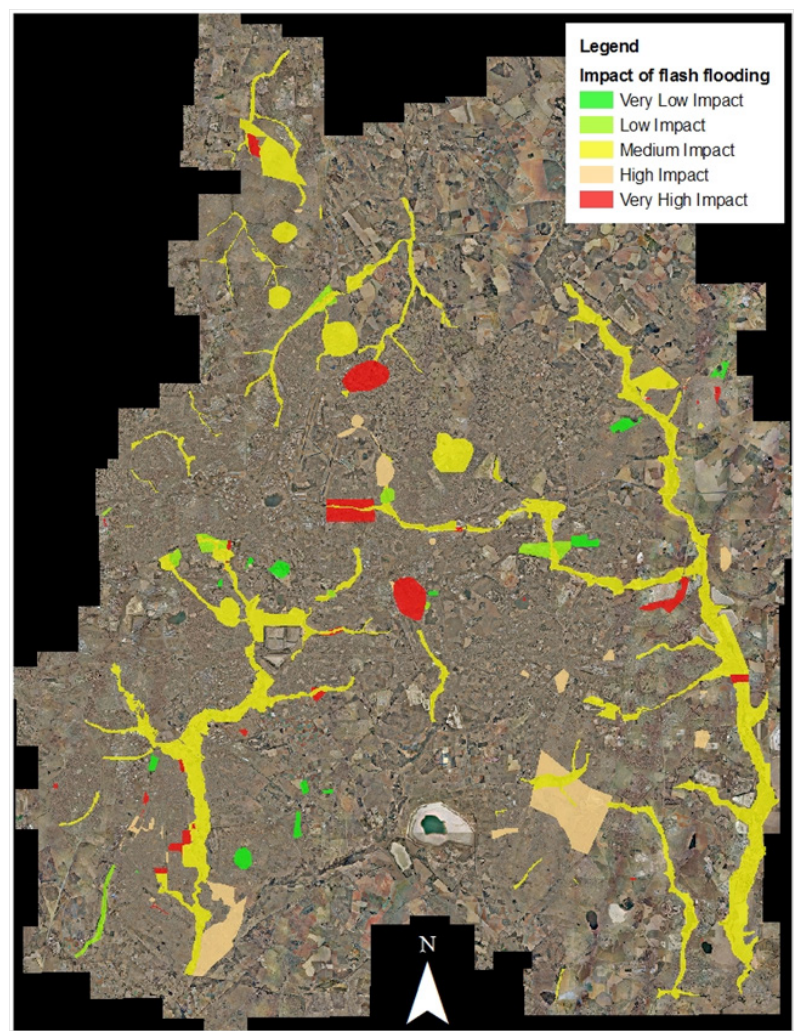

Figure 6

Indication of the flash-flooding risk zones within EMM
These results support the body of literature around risk, vulnerability and flash-flooding hazards (Douglas et al., 2008; Carmin et al., 2009; Bartlett et al., 2009; Roberts 2008, 2010a and 2010b; Fatti and Vogel, 2011; Fatti and Patel, 2013), that posits that those most at risk are the communities that, due to social status, have to situate themselves on land within the urban context that is predisposed to flash flooding. Poor communities are compelled to settle on available land, which tends to be in regions not considered suitable for development. As formal infrastructure, such as roads and buildings, is introduced into areas that are predisposed to flash flooding, flood risk and impact are exacerbated by the reduced infiltration and channelling of surface run-off (Akoon, 2010).

\section{Climate change and stream flow consequences}

Coupled to the investigation of flash flooding and vulnerable areas, potential changes in urban stream flow and flooding were also examined (e.g. flash stream flow). If climate change and variability induces increased rainfall intensities over shorter time periods as anticipated, the affected region will experience increased stream flow. Preliminary hydrological analysis in this study suggests that streams in the medium to large catchments will be most affected. Some of the anticipated stream flow consequences include: higher velocities and increased depths during storm flow; lower base flow due to a decrease in catchment infiltration during storm events; longer dry periods; and changes in geomorphology of the stream due to changing sediment loads. The anticipated changes in rainfall patterns therefore require that greater emphasis be placed on catchment-scale planning and solutions to urban drainage problems.

\section{Perceptions and responses to urban flood risks: The case of EMM}

The social dimensions of vulnerability to flooding and flood risks in the area were also probed (Fatti and Patel, 2013).

Notwithstanding the difficulty in understanding the science of climate risks and change, communities' (residents and city officials) perceptions and understanding of flooding in the area revealed important insights that can assist when trying to reduce flood risks effectively. Several of the 'vulnerabilities' obtained from both residents in the area and city managers revolved around issues of trust, perceived financial, logistical and political constraints, as well as poor maintenance and monitoring of water management infrastructure (Fatti and Patel, 2013). There was, for example, a very strong sense from the community that they did not 'trust' the municipality to reduce their flood risks. Some members of the community highlighted that rates and payments to the municipality would not be secured for adequate flood risk reduction, and that their rates would be better managed through a ratepayer's association. Residents noted that little flood-risk planning seemed evident (much development is on-going, including increased hard surfaces, road paving without appropriate stormwater control measures). Some noted that risk reduction efforts often appeared to be reactionary and short-term.

City officials from the EMM in turn also voiced concerns, several of which centred on budgetary and fiscal constraints for effective flood risk reduction. Inadequate and up-to-date planning (e.g. stormwater infrastructural plans), as well as difficulties imposed on planning because of complex policy requirements and processes (e.g. EIA), also seem to frustrate effective flood risk reduction (Fatti and Patel, 2013). Research 
in this case was investigative and probing and yet still revealed that communities and city managers have clear perceptions and understandings of flood risk that could be meaningfully harnessed to assist in effective flood risk reduction efforts.

\section{Adaptation options to reduce climate change related flood risk}

Some of the potential impacts of enhanced rainfall periods and challenges of flood risk reduction approaches are now being considered for EMM. Climate modelling results indicate that periods of extreme and severe rainfall may increase with climate change (Fig. 3, also see Engelbrecht et al., 2012). In particular, indications are that the central interior of South Africa and therefore EMM are no exceptions in this regard.

Given the modelling evidence that an increase in extreme rainfall events is plausible over much of the interior of South Africa and, given some of the impacts that have already arisen with heavy seasons of rainfall (e.g. Fatti and Vogel, 2011; flooded Kliptown area in Soweto, April, 2013 and recent flooding in early 2014 in Gauteng), it would seem timely for municipalities to seriously begin mainstreaming climate risk reduction measures into current planning portfolios. Some of the actions that could be taken, based on this research, are highlighted below.

Evidence from various assessments of storm occurrences and risk management in cities, as well as this research, enabled the development of a checklist of actions and planning that can be used to reduce flooding risks. The actions suggested (Table 2) include not only technocratic and engineering solutions but also show the need for a strong focus on the human dimensions of change, including perceptions of climate risks (Fatti and Patel, 2013). There is a range of contributing factors that result in poor governance at the local level, which in turn restricts efforts to proactively reduce risks. Inflexibility related to institutional procedures and poor communication within municipalities limits the effectiveness of proposed climate adaptation measures (Fatti and Patel, 2013).

Having studied the various responses and issues that may confront a municipality, that is, the context in which the municipality is found, one also needs to then embed the process of risk management into the wider management context, including consideration of the range of legal, policy and other governance constraints and opportunities in the water sector (e.g. DWA, 2013). A range of actions that have been adopted and augmented from an earlier assessment (Kiker, 2000), highlight adaptation options that can be considered. These were then updated with reference to and consultation with various actors in EMM (Table 2).

Responding effectively to flash flooding and other risks at local-government level will require a range of efforts. Regionallevel planning and co-ordinated use and management of the catchment and river basin will be required (e.g. Kiker, 2000), with efforts also focused on planning new infrastructure and the sustainable upgrading of existing infrastructure. There is also an opportunity for green infrastructure options, such as permeable paving, bioswales, rain gardens and wetlands, to be incorporated into the wider infrastructure network to reduce surface runoff. Identification of local risks, hazards, exposure and vulnerabilities will also be required and several cities in South Africa have already embarked on this. Allied to such efforts will be the alignment and careful planning of institutional and financial capacities and indeed legislation to effectively manage risks such as flooding (e.g., Roberts, 2008, 2010a, 2010b). Increased participation and inclusion of local communities and groups will also be required and this will require careful thinking around local risk management, including the design of more transdisciplinary approaches and social learning approaches where local perceptions and frames of reference are included in risk reduction measures (e.g. Ison et al., 2011; Lang et al., 2012; Lotz-Sisitka, 2012).

As can be seen by the various processes and types of information provided, urban flood risk management is exceedingly complex. This small research investigation has shown that simplistic notions of 'building resilience' to climate risks in a large metropolitan area such as EMM cannot occur. Businessas-usual, we believe, will not be enough to effectively adapt to climate risks and more emphasis should be given to exploring more systemic and transdisciplinary approaches to such risks and urban planning. Some radical and fundamental changes in how we approach planning and indeed processes used to plan for risks associated with climate will also be required.

\section{CONCLUSION}

In this paper, an attempt has been made to begin to examine the climate risk and planning context in an ever-changing municipal context in South Africa. The case study of EMM has shown and revealed a number of issues that have yet to be further interrogated so that effective adaptation for plausible climate risks (which include rapidly rising surface temperatures and an increase in the frequency of extreme precipitation events with a range of potential consequences) can be implemented.

Some preliminary assessments of vulnerability given heavy rainfall events have been identified and community-level framing of key issues and perceptions has also been probed. What remains is to find ways and processes to mainstream such critical activities into the overall, day-to-day planning activities of municipalities.

Ultimately we suggest that what will be required to reduce risks related to changes in climate, including changing climate variability, is indeed 'business unusual'. The current parameters and criteria for managing climate risks are changing. These are being further compounded by development challenges, as has been shown in the case of EMM. The local-level context is therefore as critical to understand, as are the broader, international and national contexts.

To move beyond just merely 'coping' with climate risks (business-as-usual) and really 'adapting' to changes (business unusual), will require champions who will begin to fully engage in such themes and to tirelessly craft a set of plans. We also urgently need a meaningful climate-risk reduction dialogue in the cities of South Africa that will enable the 'bedding' down of efforts for change, and begin a pathway to effective institutionalisation of adaptation in and for cities. Much work of this type has already begun (e.g. in eThekwini and Cape Town Metros) but more urgently needs to begin in other major centres, including Gauteng.

\section{ACKNOWLEDGEMENTS}

The authors would like to thank the Water Research Commission for funding this research (Project K5/1953). Some of the early thinking for this research was informed by inputs from Prof JoAnn Carmin of the Department of Urban Studies and Planning of MIT, Boston, USA. She sadly passed away on 15 July 2014 and we wish to honour her work and her life with this small citation and acknowledgement of her great inputs into climate change adaptation and urban governance and urban social justice issues. 


\begin{tabular}{|c|c|}
\hline \multicolumn{2}{|c|}{$\begin{array}{l}\text { TABLE } 2 \\
\begin{array}{l}\text { Water adaptation measures (adapted from Kiker, 2000, sections in italics taken from Kiker, 2000, Table 14.1, p. 62). } \\
\text { Considerations were added based on research for the EMM case study. }\end{array} \\
\end{array}$} \\
\hline Actions to be taken & Considerations \\
\hline $\begin{array}{l}\text { Plan and coordinate use of river-basin. 'Comprehensive } \\
\text { planning across a river basin will support coordinated } \\
\text { solutions to problems of water quality and water supply'. }\end{array}$ & $\begin{array}{l}\text { 'The Water Act of } 1998 \text { requires that water use should be conducted in } \\
\text { a sustainable and equitable manner. The Act mandates the creation of } \\
\text { catchment management agencies'. }\end{array}$ \\
\hline $\begin{array}{l}\text { Make marginal changes in construction of new infrastruc- } \\
\text { ture now. 'In planned construction, consider marginal } \\
\text { increases in the size of dams or marginal changes in the } \\
\text { construction of canals, pipelines, pumping plants, and } \\
\text { storm drainages'. Include alternative green infrastructure } \\
\text { approaches. }\end{array}$ & $\begin{array}{l}\text { The very preliminary assessment of a pilot catchment in EMM suggests } \\
\text { that a guideline } 10 \% \text { increase in capacity of attenuation ponds, river } \\
\text { conveyance and culvert sizes would be a reasonable design safety factor } \\
\text { to cope with predicted increases in extreme rainfall events. }\end{array}$ \\
\hline $\begin{array}{l}\text { Adapt current development control and drainage design } \\
\text { approaches. In addition to adapting current design } \\
\text { methods, switch to 'flood volume control' rather than } \\
\text { 'flood peak control'. This focuses on limiting new paved } \\
\text { surfaces and promotes infiltration techniques. }\end{array}$ & $\begin{array}{l}\text { This is central to well- established source control and sustainable } \\
\text { drainage techniques, but is not yet mainstream in planning, develop- } \\
\text { ment control and design in South Africa. Institutional adjustments are } \\
\text { required across departments in municipalities, and some local testing } \\
\text { of some of the techniques is required. }\end{array}$ \\
\hline \multicolumn{2}{|l|}{$\begin{array}{l}\text { Conserve water. 'Reducing demand can increase excess } \\
\text { supply, creating a greater margin of safety for future } \\
\text { droughts'. }\end{array}$} \\
\hline $\begin{array}{l}\text { Control pollution. 'Polluting water so that it is unfit for } \\
\text { drinking or other uses can, in many respects, have an } \\
\text { effect that is similar to reducing water supply. Reducing } \\
\text { water pollution effectively increases the supply of water'. }\end{array}$ & $\begin{array}{l}\text { The polluter-pays principle should be applied to South African } \\
\text { municipalities. }\end{array}$ \\
\hline \multicolumn{2}{|l|}{ Allocate water supplies by using market-based systems. } \\
\hline Adopt contingency planning for drought & $\begin{array}{l}\text { Measures should include but not be limited to: } \\
\text { - } \quad \text { Improving water quality in receiving streams and rivers } \\
\text { - } \quad \text { Preserving natural storage areas } \\
\text { - } \quad \text { Treating stormwater as a resource } \\
\text { - } \quad \text { Reducing drought mitigation in catchment management plans } \\
\quad \text { landscaping }\end{array}$ \\
\hline $\begin{array}{l}\text { Use interbasin transfers. 'Transfers of water between } \\
\text { water basins may result in more efficient water use under } \\
\text { current and changed climate'. }\end{array}$ & $\begin{array}{l}\text { Water resources planning may require inter-basins transfers from time } \\
\text { to time for larger municipalities in water-stressed areas. }\end{array}$ \\
\hline $\begin{array}{l}\text { Promote runoff harvesting for local use. Urban areas } \\
\text { increase runoff over natural catchment conditions. } \\
\text { Harvesting this runoff will improve catchment manage- } \\
\text { ment and water security. }\end{array}$ & $\begin{array}{l}\text { This involves more than just rainwater harvesting systems, and will } \\
\text { include catchment- scale runoff harvesting and water re-use, reducing } \\
\text { the reliance on upstream yields (including inter-basin transfers) and } \\
\text { reducing impacts on downstream users. }\end{array}$ \\
\hline Maintain options to develop new dam sites. & $\begin{array}{l}\text { Municipalities should be active and accountable in the planning and } \\
\text { decision making for new reservoirs. }\end{array}$ \\
\hline $\begin{array}{l}\text { Improve monitoring and forecasting systems for flood and } \\
\text { droughts. }\end{array}$ & $\begin{array}{l}\text { Municipal activities for this should include: } \\
\text { - Using climate model predictions to provide a baseline of frequency } \\
\text { and magnitude of floods and droughts. } \\
\text { - Developing and maintaining contingencies for coping with } \\
\text { floods and droughts (e.g. spare flood storage capacity, spare water } \\
\text { resource reserves). } \\
\text { - Including disaster management in catchment management plans. } \\
\text { - } \quad \text { Developing flood warning systems according to good practice. } \\
\text { - Ensuring the public remain well informed. }\end{array}$ \\
\hline Coordinate and integrate across departments and levels. & $\begin{array}{l}\text { All departments need to take responsibility for disaster management } \\
\text { and preparation, including climate change }\end{array}$ \\
\hline
\end{tabular}

\section{REFERENCES}

AKOON I (2010) The vulnerability of the Ekurhuleni Metropolitan Municipality to flash floods, a probable impact of climate change: A risk assessment. B.Sc. Honours dissertation, University of the Witwatersrand, Johannesburg.

BARTLETT S, DODMAN D, HARDOY J, SATTERTHWAITE D and TACOLI C (2009) Social aspects of climate change in urban areas in low and middle income nations. Contribution to the World Bank $5^{\text {th }}$ Urban Research Symposium, 28-30 June 2009, Marseille, France.

BATES BC, KUNDZEWICZ ZW, WU S and PALUTIKOF JP (eds) (2008) Climate change and water. Technical Paper of the Intergovernmental Panel on Climate Change, IPCC Secretariat, Geneva. 210 pp. 
BULKELEY H, SCHROEDER H, JANDA K, ZHAO J, ARMSTRONG A, YI CHU S, and GHOSH S (2010) Cities and Climate Change: The role of institutions, governance and urban planning, Paper presented at the Development Bank Southern Africa, November 2010.

CARTWRIGHT A (2008) A sea-level rise risk assessment for Cape Town. Report to the ERMD, City of Cape Town.

CARTWRIGHT A, PARNELL S, OELOFSE G and WARD A (2012) Climate Change at the City Scale: impacts, mitigation and adaption in Cape Town. Routledge, London. 296 pp.

CARMIN J, ROBERTS D and ANGUELOVSKI I (2009) Planning climate resilient cities: Early lessons from early adaptors. Contribution to the World Bank $5^{\text {th }}$ Urban Research Symposium, 28-30 June 2009, Marseille, France.

COLOMBO AG, HERVÁS J and ARELLANO AL (2002) Guidelines on Flash Flood Prevention and Mitigation. NEDIES Project, Report EUR 20386 EN. Luxembourg: Office of Official Publications of the European Community. 77 pp.

DEPARTMENT OF WATER AFFAIRS (2013) National Water Resource Strategy. Department of Water Affairs, Pretoria.

DOUGLAS I, ALAM K, MAGHENDA M, McDONNELL Y, McLEAN L and CAMPBELL J (2008) Unjust waters: Climate change, flooding and the urban poor in Africa. Environ. Urban. 20 187-205.

DYSON LL (2009) Heavy daily-rainfall characteristics over the Gauteng Province. Water SA 35 (5) 627-638.

EKURHULENI METROPOLITAN MUNICIPALITY (2007) Environmental Management Framework. Ekurhuleni Metropolitan Municipality, Ekurhuleni.

EKURHULENI METROPOLITAN MUNICIPALITY (2004) State of the Environment Report. Ekurhuleni Metropolitan Municipality, Ekurhuleni.

ENGELBRECHT FA, McGREGOR JL and ENGELBRECHT CJ (2009) Dynamics of the conformal-cubic atmospheric model projected climate-change signal over southern Africa. Int. J. Climatol. 29 1013-1033.

ENGELBRECHT FA, LANDMAN WA, ENGELBRECHT CJ, LANDMAN S, ROUX B, BOPAPE MM, McGREGOR JL and THATCHER M (2011) Multi-scale climate modelling over southern Africa using a variable-resolution global model. Water SA 37 (5) 647-658.

ENGELBRECHT CJ, ENGELBRECHT FA and DYSON LL (2012) High-resolution model-projected changes in mid-troposheric closed-lows and extreme rainfall events over southern Africa. Int. J. Climatol. 33 173-187. DOI: 10.1002/joc.3420.

FATTI CE and VOGEL CH (2011) Is science enough? Examining ways of understanding, coping and adapting to storm risks in Johannesburg. Water SA 37 (1) 57-65.

FATTI CE and PATEL Z (2013) Perceptions and responses to urban flood risk: Implications for climate governance in the South. Appl. Geogr. 36 13-22.

GRANBERG M and ELANDER I (2007) Local governance and climate change: Reflections on the Swedish experience. Local Environ.: Int. J. Justice Sustainability 12 (2) 537-548.

HEWITSON BC and CRANE RG (2006) Consensus between GCM climate change projections with empirical downscalings: precipitation downscaling over South Africa. Int. J. Climatol. 26 1315-1337.

IPCC (2012) Summary for policymakers. In: Field CB, Barros V, Stocker TF, Qin D, Dokken DJ, Ebi KL, Mastrandrea MD, Mach KJ, Plattner G-K, Allen SK, Tignor M and Midgley PM (eds.) Managing the Risks of Extreme Events and Disasters to Advance Climate Change Adaptation. A Special Report of Working Groups I and II of the Intergovernmental Panel on Climate Change. Cambridge University Press, Cambridge, UK, and New York, NY, USA. 1-19.

ISON R, COLLINS K, COLVIN J, JIGGINS J, ROGGERO PP, SEDDAIU G, STEYAERT P, TODERI M and ZANOLLA C (2011) Sustainable catchment managing in a climate changing world: New integrative modalities for connecting policy makers, scientists and other stakeholders. Water Resour. Manage. 25 (15) 3977-3992.

KIKER GA (2000) Synthesis Report for the Vulnerability and Adaptation Assessment Section: South African Country Study on Climate Change. Department of Environmental Affairs and
Tourism, Pretoria. URL: www.sanbi.org/countrystudy/main.htm (Accessed in July 2012).

KRUGER AC (2006) Observed trends in daily precipitation indices in South Africa: 1910-2004. Int. J. Climatol. 26 2275-2286.

LANG D, WIEK A, BERGMAN M, STAUFFACHER M, MARTENS P, MOLL P, SWILLING M and THOMAS CJ (2012) Transdisciplinarity in sustainability science: practice, principles and challenges. Sustainability Sci. Supplement $125-43$. DOI: 10.1007/ s11625-011-0149-x.

LTAS (2014) Interactive planning process, Phase 2 Climate change adaptation and human settlements, disaster risk management and reduction and scenario planning Johannesburg, South Africa, 22-24 January 2014. URL: http://www.sanbi.org/sites/ default/files/documents/documents/ltas-22-24-jan-workshopreport04-02-201409-44.pdf (Accessed 12 August 2014).

LOTZ-SISITKA H (ed.) (2012) (Re) views on social learning literature: A monograph for social learning researchers in natural resources management and environmental education. Environmental Learning Research Centre, Rhodes University/ EEASA/SADC REEP, Grahamstown/Howick.

MALHERBE J, ENGELBRECHT FA and LANDMAN WA (2012) Projected changes in tropical cyclone climatology and landfall in the Southwest Indian Ocean region under enhanced anthropogenic forcing. Clim. Dyn. DOI: 10.1007/s11540-013-9230-4.

MASON SJ and JOUBERT AM (1997) Simulated changes in extreme rainfall over southern Africa. Int. J. Climatol. 17 291-301.

MILLER K and YATES D (2006) Climate Change and Water Resources: A Primer for Municipal Water Providers. American Water Works Association, Denver. 83 pp.

MOSER C and SATTERTHWAITE D (2009) Towards pro-poor adaptation to climate change in the urban centres of low- and middleincome countries. Climate Change and Cities Discussion Paper 3. IIED, Global Urban Research Centre. URL: http://www.iied.org/ pubs/display.php?o=10564IIED (Accessed 10 February 2011).

MUKHEIBIR P and SPARKS D (2006) Climate variability, climate change and water resource strategies for small municipalities. WRC Report No. 1500/1/06. Water Research Commission. Pretoria.

MUKHEIBIR P (2007) Qualitative assessment of municipal water resource management strategies under climate impacts: The case of the Northern Cape, South Africa. Water SA 33 (4) 575-581.

NASH LL and GLEICK PH (1993) The Colorado river basin and climatic change. Pacific Institute for Studies in Development and Security, Oakland, California. Report for the United States Environmental Protection Agency. EPA 230-R-93-009, December. United States Environmental Protection Agency, Washington, DC.

POOLMAN E (2014) Personal communication, January 2014. Dr Eugene Poolman, South African Weather Service, Pretoria, South Africa.

ROBERTS D (2008) Thinking globally, acting locally - institutionalizing climate change at the local government level in Durban, South Africa. Environ. Urban. 20 521-537.

ROBERTS D (2010a) Thinking globally, acting locally: Institutional izing climate change within Durban's local government, Cities Alliance. CIVIS 3, June 2010.

ROBERTS D (2010b) Prioritizing climate change adaptation and local level resilience in Durban, South Africa. Environ. Urban. 22 (2) 397-413.

ROMERO-LANKAO P (2008) Urban areas and climate change: Review of current issues and trends. Issues Paper for the 2011 Global Report on Human Settlements 2011, 101. URL: http://www. ral.ucar.edu/staff/prlankao-staff.php (Accessed 15 October 2014).

SHAMA D and TOMAR S (2010) Mainstreaming climate chajnge adaptation in Indian Cities. Environ. Urban. 22 (2) 451-465.

SMIT B, BURTON I, KLEIN RJT and WANDEL J (2000) An anatomy of adaptation to climate change and variability. Clim. Change $\mathbf{4 5}$ 223-251.

STATS SA (STATISTICS SOUTH AFRICA) (2011) Census 2011. Statistics SA, Pretoria.

TADROSS MA, JACK C and HEWITSON BC (2005) On RCM-based projections of change in southern African summer climate. Geogr. Res. Lett. 32 L23713. DOI: 10.1029/2005GL024460. 
THE GOVERNMENT OFFICE FOR SCIENCE (2012) Foresight Reducing Risks of Future Disasters: Priorities for Decision Makers, 2012, Final Project Report. The Government Office for Science, London.

THOMPSON KLEIN J (2004) Prospects for transdisciplinarity. Futures 36 515-526.

WILBANKS T, ROMERO-LANKAO P, BAO M, BERKHOUT F, CAIRNCROSS S, CERON J, KAPSHE M, MUIR-WOOD R and ZAPATA-MARTI R (2007) Industry, settlement and society. In:
Parry M, Canziani O, Palutikof J, Van der Linden P and Hanson C (eds) Climate Change 2007: Impacts, Adaptation and Vulnerability, Contribution of Working Group II to the Fourth Assessment Report of the Intergovernmental Panel on Climate Change. Cambridge University Press, Cambridge. 357-390.

YOHE G and LEICHENKO R (2010) Adopting a risk-based approach. Chapter 2. New York City Panel on Climate Change 2010 Report. Ann. New York Acad. Sci. 1196 29-40. 